\title{
Genetic Variation of Common Ash (Fraxinus excelsior L.) Populations From Provenance Regions in Southern Germany by Using Nuclear and Chloroplast Microsatellites
}

\author{
By I. HeBeL ${ }^{1), 2)}$, R. HAAs ${ }^{1)}$ and A. Dounavi $\left.{ }^{1), *}\right)$ \\ Forest Research Institute of Baden-Württemberg, Division of Forest Ecology, \\ Wonnhaldestr. 4, 79100 Freiburg, Germany
}

(Received $1^{\text {st }}$ August 2005)

\begin{abstract}
The genetic structure of 14 populations from three ash provenance regions (Fraxinus excelsior L.) in southern Germany (Aid Infodienst, 2003) is described by analysing the variation of four nuclear and five cpDNA microsatellites. The study of the nuclear microsatellites revealed high levels of genetic diversity but low levels of genetic differentiation, suggesting a high degree of gene flow among regions and/or human interference by introducing plant material coming from different provenances. The distributions of the allele frequencies and the genetic structures at these four microsatellite loci did not allow the identification of distinct provenance regions, although "private alleles" were encountered with moderate to low frequencies (above 5 percent). Specifically, the Rhine valley populations (provenance region 81105) and these from the Swabian Jura and Black Forest (provenance region 81107) revealed private alleles at the two microsatellite loci Femsatl4 and Femsatl12. A more distinct differentiation between provenances was found based on the cpDNA markers. Evidence on genetic delineation and characterization of ash provenances is discussed. Based on these results, provenance regions can be genetically characterised but further analysis of ash populations and of reproductive material (seeds or seedlings) would be of great importance for provenance delineation, as well as gene conservation and sustainable management of ash populations.
\end{abstract}

Key words: common ash, Fraxinus excelsior, genetic variation, microsatellites, genetic structure, differentiation of populations.

\section{Introduction}

The distribution of common ash (F. excelsior L.) in Europe was a result of its expansion in the early Holocene period from four main refugia regions, one located in the Apeninnes, one in the eastern Alps, one on the Iberian and one on the Balkan peninsula (HEUERTZ et al., 2004b). The common ash is one of the European hardwood tree species that is highly represented in the

\footnotetext{
1) Forest Research Institute of Baden-Württemberg, Division of Forest Ecology, Wonnhaldestr. 4, 79100 Freiburg, Germany.

2) Albert-Ludwigs-Universität Freiburg, Biology Faculty, Institute for Biology II, Division Geobotany, Schänzlestr. 1, 79104 Freiburg, Germany.

*) Author for correspondence: AIKATERINI DounAVI, Forest Research Institute of Baden-Württemberg, Division of Forest Ecology, Wonnhaldestr. 4, 79100 Freiburg, Germany. Phone +49-761-4018159, Fax +49-761-4018333, e-mail: aikaterini. dounavi@forst.bwl.de
}

populations across the Rhine River. The present forests in this region were mainly developed as a result of Rhine straightening and re-established through planting of soft- and hardwoods (VOLK, 2001). It is known through historical records that over hundreds of years, settlement in the flood plain and clear-cutting of the forests for timber use reduced the distribution of ash to a few patches of scarcely wooded areas. The existence of ash in the Black Forest and in Swabian Jura was mainly influenced from the land use history of these mountainous areas. Nevertheless, the development of ash forests seems to have been in a natural way without introduction of plant material from other regions (pers. communication with foresters of the area).

The successful development and use of nuclear and chloroplast microsatellites for ash (HEUERTZ et al., 2001; LEFORT et al., 2000) presented interesting results in populations from northern and southern Europe (HEUERTZ et al., 2001; Heuertz et al., 2004a, b; HöLTKEN et al., 2003). In these studies, relatively high genetic differentiation was observed among relatively isolated ash populations in south-eastern Europe, whereas populations from a large area in western and central Europe were genetically more homogeneous (HEUERTZ et al., 2001; Heuertz et al., 2004a). However, so far no intensive studies have been carried out on the genetic differentiation of German populations.

Provenance regions are usually geographically defined, based on the conditions which characterize the habitat where the populations grow, without taking into consideration any genetic aspects (Anlage I zu Artikel 1 Nr. 5 der Ersten Verordnung zur Änderung der Forstsaat- Herkunftsgebietsverordnung, 2003). In this context, provenance regions have been defined in Germany for ecologically and economically important tree species. These provenance regions are delineated according to climatic and site conditions, assuming that populations have been well adapted under local conditions over the years (aid Infodienst, 2003; Anlage I zu Artikel 1 Nr. 5 der Ersten Verordnung zur Änderung der Forstsaat- Herkunftsgebietsverordnung, 2003).

In the present paper a genetic diversity study of $F$. excelsior in southern Germany is described using nuclear and chloroplast microsatellites with the main objective to genetically characterise different provenance regions, defined according to the German legislation (Anlage I zu Artikel 1 Nr. 5 der Ersten Verordnung 
zur Änderung der Forstsaat- Herkunftsgebietsverordnung, 2003). Moreover, the extent to which the different refugial populations have contributed to the present populations of $F$. excelsior in southern Germany will be inferred by using cpDNA-markers.

\section{Materials and Methods}

\section{Plant material}

Samples of Fraxinus excelsior L. were collected in summer 2003 from three regions of provenance in southern Germany: 81105 (Upper Rhine Valley), 81107 (Black Forest and Swabian Jura), and 81108 (Bavarian Alps and foothills). Three populations in the provenance region 81108 (Bavarian Alps and foothills), four in the region 81107 (Black Forest and Swabian Jura) and seven in the region 81105 (Upper Rhine valley) with a representative spatial distribution in each provenance were chosen as sampling areas. In these sampling areas (5-10 ha), trees were selected randomly but with two restrictions: a. to be widely spaced in order to avoid sampling of members of the same family, and b. to represent the spatial distribution of trees in the forest unit. Seventy trees from each population of the regions 81108 and 81107, and forty trees from each population of the region 81105 were selected; leaves were sampled from a total of 280 trees from each of the provenance regions 81105 and 81107 and from 210 trees from the region 81108. The number of samples scored for all four microsatellite loci in each region is presented in Tab. 1 . Samples from 15 to 20 trees per population were used for the cp-DNA analysis. The leaves were frozen under dry conditions before DNA was extracted. The locations of the sampled populations in each provenance are presented in Figure 1. According to the delineation of provenance regions, the populations from the Swabian Jura

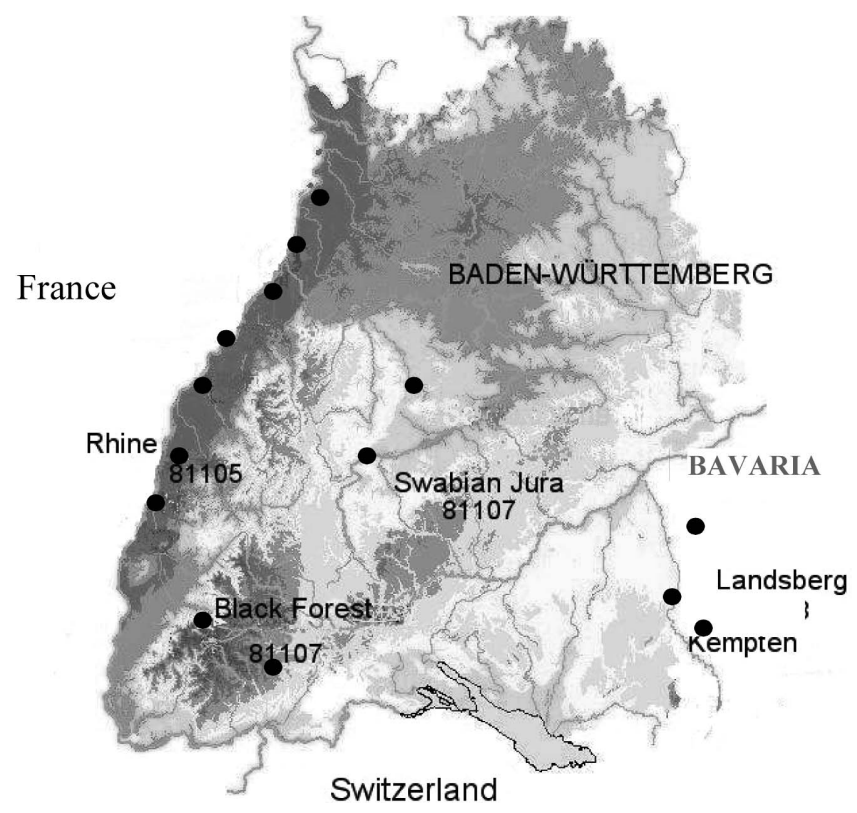

Figure 1. - Location of the study populations in the three provenance regions in Baden-Württemberg (Upper Rhine valley: Oberrheingraben 81105, Swabian Jura and Black Forest: Süddeutsches Hügel-und Bergland 81107, Bavaria: Alpen und Alpenvorland 81108). and the Black Forest belong to the same provenance region and are assumed to grow under similar mountainous conditions.

\section{DNA extraction - microsatellite analysis}

We extracted total DNA from approximately $50 \mathrm{mg}$ fresh leaf material or $10-20 \mathrm{mg}$ of dried plant tissue from 250 trees from each provenance, using the DNeasy Plant Mini Kit (Qiagen, Hilden, Germany). DNA extracts were fluorimetrically quantified (DyNA Quant 200 , Hoefer Pharmacia Biotec) and adjusted to $2 \mathrm{ng} / \mu \mathrm{L}$, or diluted according to visual quantification on agarose gels.

The genotypes of all investigated samples were scored at four highly polymorphic nuclear microsatellite loci, namely Femsatl4, Femsatl8, Femsatl12, Femsatl16 (BRACHET et al., 1999; LEFORT et al., 1999) and at five chloroplast microsatellites, namely ccmp3, ccmp6, ccmp7, ccmp10, ukk3 (WEISING and GARDNER, 1999; Deguilloux et al., 2003). PCR amplifications were performed using fluorescent labelled primers in a mixture containing $1 \mathrm{x}$ reaction buffer (Eppendorf), $2.5 \mathrm{mM}$ $\mathrm{MgCl}_{2}, 200 \mu \mathrm{M}$ dNTP; $0.2 \mu \mathrm{M}$ of each primer, 0.8 unit Hot Start Taq Polymerase (Eppendorf) and 5-50 ng of template DNA for a $25 \mu \mathrm{l}$ reaction volume. For the nuclear microsatellites, after an initial denaturation step for $2 \mathrm{~min}$ at $94^{\circ} \mathrm{C}$, the amplification reaction was carried out for 35 cycles as follows: $94^{\circ} \mathrm{C}$ for $1 \mathrm{~min}, 52^{\circ} \mathrm{C}$ (Femsatl8, Femsatl12, Femsatl16) or $55^{\circ} \mathrm{C}$ (Femasatl4) for $1 \mathrm{~min}$, and $72^{\circ} \mathrm{C}$ for $1 \mathrm{~min}$. The final elongation was at $72{ }^{\circ} \mathrm{C}$ for $10 \mathrm{~min}$. For the chloroplast microsatellites the reaction changed as follows: the amplification was performed in 30 cycles, with an annealing temperature of $57^{\circ} \mathrm{C}$ for ccmp3, ccmp6, ccmp7, ccmp 10 or $45^{\circ} \mathrm{C}$ for ukk3 for $1 \mathrm{~min}$. The PCR reactions were conducted on a gradient PCR-cycler (MJResearch PTC-200). The quality of the PCR products was controlled in a $1.5 \%$ agarose gel.

The sizes of the PCR products were determined by using an automatic sequencer analyser (ABI3100-Avant Genetic Analyser; Applied Biosystems). The PCR products were multiplexed in the case of Femsatl8 and Femsatl16 and analysed simultaneously by using an internal size standard (GeneScan ROX400-HD Size Standard). Size determination and allele assignment were carried out using Genemapper v.3.5 software (Applied Biosystems). Allele binning (allele specification) was based on graphics with consecutive fragment lengths per locus.

\section{Population genetic statistical analyses}

The genetic diversity within provenance regions was estimated on the basis of nuclear microsatellites by calculating several genetic parameters: number of alleles per locus and region, total number of alleles per locus, observed heterozygosity $\left(\mathrm{H}_{\mathrm{o}}\right)$ and expected heterozygosity $\left(\mathrm{H}_{\mathrm{e}}\right)$ with the software POPGENE v. 1.32 (YEH and Boyle, 1997; Yeh et al., 2001). The fixation index $\left(\mathrm{F}_{\mathrm{IS}}\right)$ was used as a measure of heterozygote deficiency or excess and genetic differentiation among provenance regions was estimated by their $\mathrm{F}_{\mathrm{ST}}$ values (WEIR and 
Cockerham, 1984). The F-values were calculated and tested by using the software FSTAT v. 3.4 (GOUDET, 1995).

\section{Results}

\section{Nuclear microsatellites}

All of the nuclear microsatellite loci turned out to be highly polymorphic possessing large numbers of alleles, while the effective numbers of alleles $\left(n_{e}\right)$ were considerably lower for all of them. In the total sample, allele numbers per locus varied between 27 (Femsatl12, Femsatl16) and 41 (Femsatl4) (Tab. 1). The observed heterozygosity $\left(\mathrm{H}_{\mathrm{o}}\right)$ was lower than the expected $\left(\mathrm{H}_{\mathrm{e}}\right)$ in most of the populations and at most of the loci, leading to positive estimates of inbreeding coefficients $\left(\mathrm{F}_{\mathrm{IS}}\right)$ except in the case of the populations in the regions 81107 (Femsatl8) and 81108 (Femsatl8, Femsatl16) where the $\mathrm{F}_{\text {IS }}$ values were negative (Tab. 1). The hypothesis of Hardy-Weinberg structure was rejected for all regions and most of the loci $(\mathrm{P}>0.05)(T a b .1)$. The populations of the provenance region 81105 (Rhine valley) showed the highest inbreeding coefficient $\left(\mathrm{F}_{\text {IS }}=0.095\right)$ over all loci, while the lowest value was observed in the populations of the provenance region 81108 (Bavaria) $\left(\mathrm{F}_{\text {IS }}=0.055\right)$, supporting the assumption that the three ash populations sampled in Bavaria (81108) were autochthonous (personal communication with the Bayerisches Amt für forstliche Saat- und Pflanzenzucht, Teisendorf) (Tab. 1). The overall values for each loci over all populations were calculated and the highest one was calculated for Femsatl12 (Tab. 1). In this investigation we used the computer program GENEPOP 3.4 (Update of GENEPOP 1.2: RAYMOND and ROUSSET, 1995) to infer the presence of null alleles by testing the hypothesis that null alleles were responsible for high rates of homozygotes. Accordingly, the frequency of the supposed null allele under Hardy-Weinberg equilibrium should be equal to "p". In this case, the frequency of homozygotes for the supposed null allele in each locus was equal to $\mathrm{p}^{2}$, representing the individuals failed to produce any PCR fragment. According to this assumption we estimated the frequency of the supposed null allele for Femsatl12 and Femsatl16. The frequency of the null allele for each locus was estimated and ranged from 0.13 (Femsatl12) to 0.31 (Femsatl16) (data not shown).

The $\mathrm{F}_{\mathrm{ST}}$ values indicated a relatively low genetic differentiation (0.012) among the regions, a value not significantly different from $\mathrm{R}_{\mathrm{ST}}(0.004)$ (Tab. 2). The nonsignificant $\mathrm{R}$ - and $\mathrm{F}$-values indicate similar contributions of mutation and migration to the genetic variation of the populations (Tab. 2). The genetic distances (NEI,

Table 1. - Population genetic statistics of populations from three ash provenance regions based on four nuclear microsatellite loci $\left(\mathrm{N}=\right.$ number of individuals, $\mathrm{n}_{\mathrm{a}}$ and $\mathrm{n}_{\mathrm{e}}=$ observed and effective number of alleles per locus (HARTL and CLARK, 1989), $\mathrm{H}_{\mathrm{o}}$ and $\mathrm{H}_{\mathrm{e}}=$ observed and expected heterozygosity, $\mathrm{F}_{\mathrm{IS}}=$ average inbreeding coefficient, $* * * \mathrm{P}<0.001)$.

\begin{tabular}{|c|c|c|c|c|}
\hline \multirow{2}{*}{$\begin{array}{l}\text { Loci } \\
\text { Locus }\end{array}$} & \multicolumn{3}{|c|}{ Provenance } & \multirow[b]{2}{*}{ All pop } \\
\hline & 81105 & 81107 & 81108 & \\
\hline \multicolumn{5}{|c|}{ Femsatl4 } \\
\hline $\mathrm{N}$ & 250 & 246 & 200 & \\
\hline $\mathrm{n}_{\mathrm{a}}$ & 39 & 28 & 19 & 41 \\
\hline $\mathrm{n}_{\mathrm{e}}$ & 8.993 & 7.897 & 6.774 & 8.901 \\
\hline $\mathrm{H}_{\mathrm{o}}$ & 0.827 & 0.790 & 0.729 & $0.804 * * *$ \\
\hline $\mathrm{H}_{\mathrm{e}}$ & 0.888 & 0.873 & 0.852 & 0.888 \\
\hline $\mathrm{F}_{\text {IS }}$ & 0.077 & 0.069 & 0.162 & 0.103 \\
\hline \multicolumn{5}{|c|}{ Femsatl 8} \\
\hline $\mathrm{n}_{\mathrm{a}}$ & 36 & 33 & 30 & 38 \\
\hline $\mathrm{n}_{\mathrm{e}}$ & 15.208 & 17.265 & 19.4841 & 18.576 \\
\hline $\mathrm{H}_{\mathrm{o}}$ & 0.882 & 0.942 & 0.969 & 0.910n.s. \\
\hline $\mathrm{H}_{\mathrm{e}}$ & 0.934 & 0.938 & 0.949 & 0.946 \\
\hline $\mathrm{F}_{\mathrm{IS}}$ & 0.054 & -0.026 & -0.014 & 0.005 \\
\hline \multicolumn{5}{|c|}{ Femsatl12 } \\
\hline $\mathrm{n}_{\mathrm{a}}$ & 26 & 16 & 18 & 27 \\
\hline $\mathrm{n}_{\mathrm{e}}$ & 5.403 & 3.442 & 4.382 & 4.651 \\
\hline $\mathrm{H}_{\mathrm{o}}$ & 0.626 & 0.506 & 0.521 & $0.577 * * *$ \\
\hline $\mathrm{H}_{\mathrm{e}}$ & 0.815 & 0.709 & 0.772 & 0.785 \\
\hline $\mathrm{F}_{\mathrm{IS}}$ & 0.157 & 0.198 & 0.222 & 0.192 \\
\hline \multicolumn{5}{|c|}{ Femsatl16 } \\
\hline $\mathrm{n}_{\mathrm{a}}$ & 21 & 19 & 20 & 27 \\
\hline $\mathrm{n}_{\mathrm{e}}$ & 2.317 & 1.771 & 3.358 & 2.236 \\
\hline $\mathrm{H}_{\mathrm{o}}$ & 0.515 & 0.341 & 0.812 & $0.498 * * *$ \\
\hline $\mathrm{H}_{\mathrm{e}}$ & 0.568 & 0.435 & 0.702 & 0.553 \\
\hline $\mathrm{F}_{\mathrm{IS}}$ & 0.091 & 0.115 & -0.152 & 0.019 \\
\hline \multicolumn{5}{|c|}{ All loci } \\
\hline $\mathrm{H}_{\mathrm{o}}$ & 0.712 & 0.643 & 0.758 & \\
\hline $\mathrm{H}_{\mathrm{e}}$ & 0.801 & 0.740 & 0.819 & \\
\hline $\mathrm{F}_{\mathrm{IS}}$ & 0.095 & 0.089 & 0.055 & \\
\hline
\end{tabular}


Table 2. - Population differentiation statistics and gene flow $\left(\mathrm{N}_{\mathrm{m}}=\right.$ number of migrants among regions, $\mathrm{F}_{\mathrm{IT}}=$ overall inbreeding coefficient).

\begin{tabular}{|c|c|c|c|c|}
\hline & & \multicolumn{2}{|c|}{$\begin{array}{l}\text { Differentiation among } \\
\text { provenance regions }\end{array}$} & $\begin{array}{l}\text { Gene flow among } \\
\text { provenance regions }\end{array}$ \\
\hline Locus & $\begin{array}{l}\text { Overall inbreeding } \\
\mathrm{F}_{\mathrm{IT}}\end{array}$ & $\mathrm{F}_{\mathrm{ST}}$ & $\mathrm{R}_{\mathrm{ST}}$ & $\mathrm{Nm}$ \\
\hline Femsatll4 & 0.112 & 0.010 & 0.004 & 10.928 \\
\hline Femsatl8 & 0.014 & 0.009 & 0.007 & 14.698 \\
\hline Femsatl12 & 0.200 & 0.010 & 0.007 & 9.566 \\
\hline Femsatl16 & 0.043 & 0.024 & -0.001 & 7.327 \\
\hline Mean & 0.092 & 0.012 & 0.004 & 10.454 \\
\hline
\end{tabular}

Table 3. - Genetic distances (NEI, 1972) between provenance regions.

\begin{tabular}{lll}
\hline Provenance & 81105 & 81107 \\
\hline 81105 & - & \\
81107 & 0.056 & - \\
81108 & 0.063 & 0.067 \\
\hline
\end{tabular}

1972) among the populations of the different provenance regions were relatively low with the highest value between regions 81107 and 81108 (Tab. 3). The allele frequency distributions were very similar for all nuclear loci in all three provenance regions. A qualitative differentiation among the regions was found in private alleles with frequencies higher than four and lower than ten percent for the loci Femsatl4 (81107) and Femsatl12 (81105) (Fig. 2).

\section{Chloroplast microsatellites}

One of the five chloroplast microsatellites analysed (ccmp3) was monomorphic with a fragment length of 91 bp. The other four showed low levels of polymorphism; ccmp6 and ccmp7 presented two size variants, whereas the ccmp10 and $\mu \mathrm{kk} 3$ showed three size variants, separated by one nucleotide. Tab. 4 lists the six haplotypes comprising the combinations of the size variants observed for each cpDNA marker. According to the findings in each population of the three provenance regions the haplotypes A and B represented the $52 \%$ and $44 \%$ of the total number of trees analysed, respectively. We found three common haplotypes found also by HEUERTz et al. (2004b), whereby in our study one of them was divided into two due to the use of an additional marker. Furthermore, one previously not reported haplotype was found.

\section{Femsatl4}
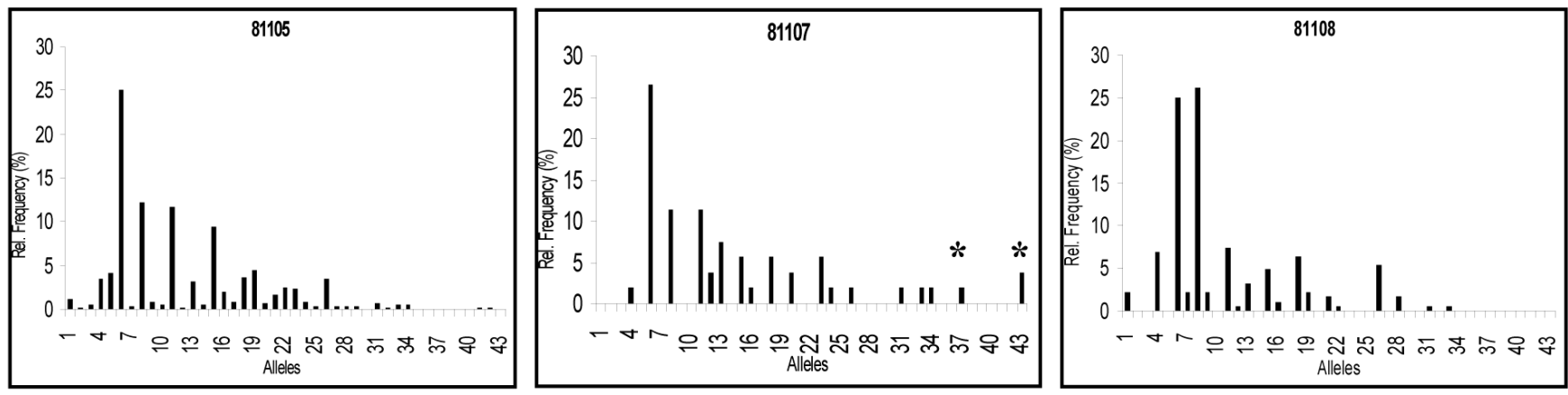

Femsatl12
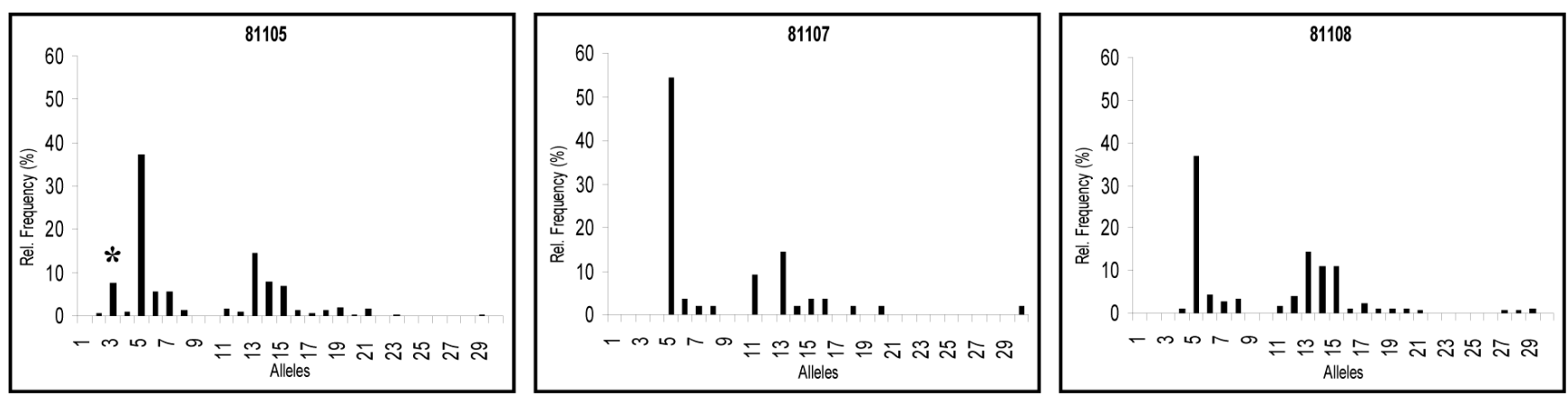

Figure 2. - Allele distributions for the two nuclear microsatellites (Femsatl4, Femsatl12), showing private alleles (*) encountered in for populations of the two provenance regions 81105 and 81107. 
Table 4. - Chloroplast haplotypes observed in the three provenance regions based on five cpDNA microsatellites.

Haplotypes N Size of amplified fragment

\begin{tabular}{ccccccc}
\hline & & ccmp3 & ccmp6 & ccmp7 & ccmp10 & $\mu \mathrm{kk3}$ \\
\hline A & 91 & 91 & 93 & 111 & 98 & 92 \\
B & 77 & 91 & 93 & 111 & 97 & 92 \\
C & 4 & 91 & 93 & 111 & 98 & 90 \\
D & 2 & 91 & 92 & 112 & 98 & 92 \\
E & 1 & 91 & 93 & 111 & 98 & 91 \\
F & 1 & 91 & 93 & 111 & 99 & 92 \\
\hline
\end{tabular}

In $93 \%$ of the samples of the Rhine valley (81105), haplotypes A and B were present, while two other haplotypes ( $\mathrm{C}$ and $\mathrm{E}$ ) were only rarely found. In all regions the frequency of the haplotype $\mathrm{A}$ is higher than that of $\mathrm{B}$ (Fig. 3). The haplotype D was found only in Bavaria (81108). Finally, in the populations of Black Forest and Swabian Jura (provenance region 81107) only haplotype B was present (Fig. 3).

\section{Discussion}

The nuclear microsatellite analysis showed a high degree of polymorphism in all populations, detecting three times more alleles than the first investigations in ash (BRACHET et al., 1999; LEFORT et al., 1999). In concordance with the results of HöLTKEN et al., (2003) we observed a small effective allele number, indicating that just a few frequent alleles and many rare ones were present.

The deficiency of heterozygotes led to partially higher estimates of $\mathrm{F}_{\text {IS }}$ for some populations, which could be explained by the presence of null alleles, a high rate of selfing/inbreeding, restricted seed and moderate pollen

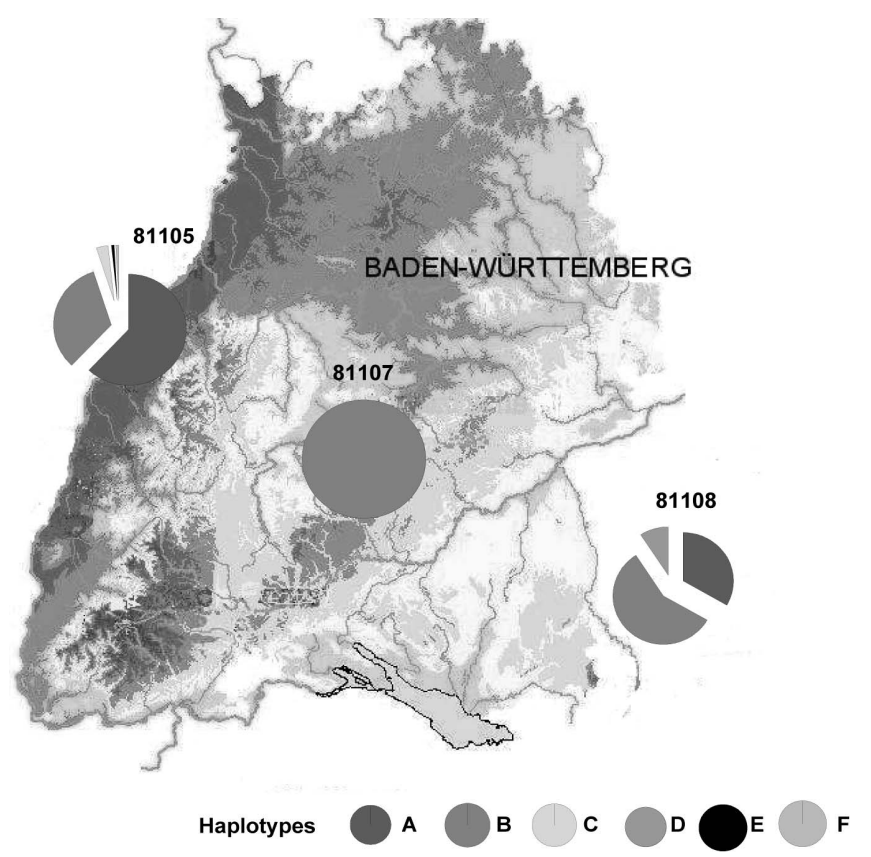

Figure 3. - Spatial distribution of haplotypes in the three provenance regions in southern Germany. dispersal (HEUERTz et al., 2003) or Wahlund effect due to fine scale genetic structuring. Actually, the frequencies of the eventual null alleles estimated in our study were relatively high in comparison to the frequencies of the other alleles observed, making their existence more unlikely. Similar results were obtained from MoRAND et al. (2002) for the microsatellite loci Femsatl11 and Femsatl19. As a second reason for the excess of homozygotes, we can assume a Wahlund effect, due to the presence of breeding subunits inside the study regions. Wahlund effects have been encountered in various populations, when highly polymorphic markers were used for the analysis (GIBss et al., 1997; Goossens et al., 2001; MorAND et al., 2002; BotTin et al., 2005). In our study a spatial Wahlund effect, generated due to sampling of breeding subunits was avoided, by sampling the mother trees being at least $50 \mathrm{~m}$ from one another. Nevertheless, a temporal Wahlund effect, due to difference in within-year flowering phenology or by variation in flowering expression of individuals between years cannot be excluded. However, the existence of Wahlund effects seemed to be unlikely in a study of French ash populations (MORAND et al., 2002). Finally, intensive human activities in the ash forests, for example planting at the Rhine valley or intensive silviculture in the Black Forest, could also be responsible for high F-values.

The qualitative differentiation among populations of different provenance regions on the basis of private alleles at the loci Femsatl4 and Femsatl12 in the populations of the provenance regions 81105 and 81107 respectively, indicates a differentiation of both of them from the provenance region 81108 . These results are in accordance with those of the cpDNA analysis which show that in the populations of the provenance region 81107 only the haplotype B was present, whereby in the populations of the provenance region 81105 most of the observed haplotypes (A, B, C, E, F) were observed. Additionally, the provenance region 81108 contains the rare haplotype $\mathrm{D}$ that was not observed in any population of the other provenance regions in south Germany.

The Rhine populations (81105) possess haplotypes originating from the refugial region located in the Apennines and the western haplotype lineage is observed in Bavaria (81108). The low number of haplotypes found in the populations of the provenance region 81107 which is located very central in southern Germany, where an overlapping of western and eastern lines should be 
expected, indicates human influence leading to genetic erosion of ash populations in these regions. Populations of this provenance region (81107) were not investigated before by other authors and were also not included in the German study areas by HeuERTz et al. (2004b).

A more natural development of the forests requires the use of plant material derived from local populations, ensuring their survival under similar environmental conditions. In general, our study on the genetic diversity of ash provenances in southern Germany provides information about the genetic delineation of ash provenances. Based on our results, provenance regions can be genetically identified at least for core areas, taking into consideration the difficulty to define the exact physical border between provenance regions. Specifically, the findings on the nuclear microsatellites show differentiation mainly between the populations of the provenance regions 81105 and 81107 in private alleles, whereby the chloroplast DNA analysis provided a distinct differentiation of the populations from the region 81108 based on a private haplotype. Consequently, the proper choice of plant material to be used for planting can be achieved by using both type of markers. Finally, these results contribute to the establishment of management tools for populations of different provenances and the delineation of gene conservation ash stands. In this case, conservation of ash populations is considered based on the neutral genetic markers, like the nuclear and chloroplast microsatellites, but adaptive gene loci should be considered as well. The genetic conservation of ash stands in the Rhine valley is important, since they possess high levels of haplotypic variation and also a rare cpDNA haplotype not found elsewhere in Germany (haplotype F). Additionally, Bavarian populations should also be genetically conserved, since they possess the haplotype $D$ not found elsewhere in Germany, according to Heuertz et al. (2004). Moreover, in the delineation of regions of provenance genetic aspects should be also considered together with geographical and ecological criteria, since genetic identification of provenance regions seems to be possible in ash based mainly on the combination of private alleles by nuclear microsatellites (Fig. 2) and/or private haplotypes by chloroplast genetic markers (Fig. 3). At the same time, other factors, i.e. natural origin and autochthony of the stands, level of human influence etc. should be taken into consideration, although present legislation does not account for this.

The distribution of genetic variation at selectively relevant gene loci is influenced by the environmental heterogeneity and causes adaptation of these populations to their local environments, resulting in an eventually fine-scale microgeographical variation. Depending on the variation pattern of selecting environmental factors the study of adaptive markers, like isozyme gene loci or the expression of specific genes of known function, would be very useful in order to understand the selection processes taking place under different environmental conditions. For example, the expression of specific genes under frequently faced stress conditions (eg. flood in the Rhine valley), would be of great importance. Such adaptive markers are already known in forest trees, like spruce (Vornam et al., 2003) and oaks (PoRTH et al.,
2005). Thus, in agreement with the suggestion of HEUERTz et al. (2004b), the combination of both types of markers would be helpful for management decisions in ash forests.

\section{Acknowledgements}

We thank M. KARopKA, H. Sснотт, K. SсHотt, U. Engist, CH. Wessel for their assistance with the sampling and for their expert plant care. We also thank A. Hoffmann and S. Seibel for their help in the laboratory; I. BROMLEY for the language revision. This study was financially supported from BW-Plus (Forschungszentrum Karlsruhe) with grant No. BWR-22016.

\section{References}

Aid Infodienst (2003): Forstliches Vermehrungsgut: Information für die Praxis, pp. 1-58 (where published?).

Bottin, L., D. Verhaegen, J. Tassin, I. Olivier, A. VailLANT and M. J. BouveT (2005): Genetic diversity and population structure of an insular tree, Santalum austrocaledonicum in New Caledonian archipelago. Molecular Ecology 14: 1979-1989.

Brachet, S., M. F. Jubier, M. Richard, B. Jungmuller and N. Frascaria-LaCOSTE (1999): Rapid identification of microsatellite loci using 5' anchored PCR in the common ash Fraxinus excelsior. Molecular Ecology 8: $160-163$.

Deguilloux, M. F., S. Dumolin-Lapègue, L. Gielly, D. GRivet and R. J. Petit (2003): A set of primers for the amplification of chloroplast microsatellites in Quercus. Molecular Ecology Notes 3: 24-27.

Gibbs, H. L., K. A. Prior, P. J. Weatherhead and G. JohnSON (1997): Genetic struxture of populations of the threatened eastern massasauga rattlesnake, Sitrurus $c$. catenatus: evidence from microsatellite DNA markers. Molecular Ecology 6: 1123-1132.

Goossens, B., L. Chicki, P. TABerlet, L. P. Waits and D. Allaine (2001): Microsatellite analysis of genetic variation among and within Alpine marmot populations in the French Alps. Molecular Ecology 10: 41-52.

GOUDET, J. (2001): FSTAT, a program to estimate and test gene diversities and fixation indices (version 2.9.3). Available from http://www.unil.ch/izea/softwares/fstat. html.

Heuertz, M., J. F. Hausman, I. Tsvetkov, N. FrascariaLACOSTE and X. VEKEMANs (2001): Assessment of genetic structure within and among Bulgarian populations of the common ash (Fraxinus excelsior L.). Molecular Ecology 10: 1615-1623.

Heuertz, M., X. Vekemans, J.-F. Hausman, M. Palada and O. J. HARDY (2003): Estimating seed vs. Pollen dispersal from spatial genetic structure in the common ash. Molecular Ecology 12: 2483-2495.

Heuertz, M., J. F. Hausman, O. Hardy, G. G. Vendramin, N. Frascaria-Lacoste and X. Vekemans (2004a): Nuclear microsatellites reveal contrasting patterns of genetic structure between western and southeastern European populations of the common ash (Fraxinus excelsior L.) L.). Evolution 58: 976-988.

Heuertz, M., S. Fineschi, M. Anzidei, R. Pastorelli, D. Salvini, L. Paule, N. Frascaria-lacoste, O. J. Hardy, X. Vekemans and G. G. VendRamin (2004b): Chloroplast DNA variation and postglacial recolonization of common ash (Fraxinus excelsior L.) in Europe. Molecular Ecology 13: 3437-3452. 
Höltken, A. M., J. TÄHtinen and A. PAPPINEN (2003): Effects of discontinuous marginal habitats on the genetic structure of common ash (Fraxinus excelsior L.). Silvae Genetica 52: 206-212.

Lefort, F., S. Brachet, N. Frascaria-Lacoste, K. J. EDWARDS and G. C. Douglas (1999): Identification and characterization of microsatellite loci in ash (Fraxinus excelsior L.) and their conservation in the olive family (Oleaceae). Molecular Ecology 8: 1075-1092.

Morand, M. E., S. Brachet, P. Rossignol, J. Dufour and N. Frascaria-Lacoste (2002): A generalized heterozygote deficiency assessed with microsatellites in French common ash populations. Molecular Ecology 11: 377-385.

NEI, M. (1972): Genetic distance betweeen populations. American Naturalist 106, 283-292.

Porth, I., C. Scotti-Saintagne, T. Barreneche, A. KreMER and K. BURG (2005): Linkage mapping of osmotic stress induced genes of oak. Tree Genetics and Genomes 1: 31-40.

RAYMOND, M. and F. Rousset (1995): GENEPOP (version 1.2: population genetics software for exact tests and ecumenicism. Journal of Heredity 86: 248-249.
VoLK, H. (2001): Auewaldforschung am Rhein - welche Wälder sind auetypisch? Natur und Landschaft 76: 520-528.

Vornam, B., C. BlöDner, R. Schubert, R. BAumann, G. Müller-Starck, H. H. Hattemer and A. Polle (2003): Preliminary results of expression profiling of spruce (Picea abies (L.) Karst.) in response to drought stress, pp. 109-113, in proceedings: Free radicals and oxidative stress: chemistry, biochemistry and pathophysiological implications, Ioannina, Greece, June 26-29.

WeIR, B. S. and C. C. Cockerham (1984): Estimating Fstatistics for the analysis of population structure. Evolution 38: 1358-1370.

YEH, F., and T. BOYLE (1997): Population genetic analysis of co-dominant and dominant markers and quantitative traits. Belgian Journal of Botany 129: 157.

YeH, F., R.-C. YANG and T. BoYle (2001): Population Genetic (Popgene, Version 1.32). http://www.ualberta.ca/ $\sim$ fyeh/info.htm.

\section{Book-Review}

\begin{abstract}
Mitteilungen der Deutschen Dendrologischen Gesellschaft - Nr. 90. Von H.-H. JESCH (Red.). 2005. Verlag Eugen Ulmer, Stuttgart, ISBN 3-8001-8325-0. 232 Seiten mit Farb-Fotos und Tabellen. Gebunden. 34,00 EUR (D), (Bezug über den Verlag oder die Deutsche Dendrologische Gesellschaft, Auf dem Steg 40, 54311 Trierweiler).
\end{abstract}

Seit der Gründung der Deutschen Dendrologischen Gesellschaft (DDG) im Jahre 1892 erscheinen die Mitteilungen der Deutschen Dendrologischen Gesellschaft. Sie wurden bis in den 2. Weltkrieg (1942) jährlich und danach in unregelmäßiger Folge etwa alle 2 Jahre herausgegeben. Seit 1998 erscheinen die Mitteilungen unter Mitarbeit von I. Grund, F.-G. Schroeder und G. SEEHANN wieder jährlich.

Der vorliegende 90. Band enthält 18 Beiträge: wissenschaftliche Arbeiten, dendrologische Beobachtungen und einen Reisebericht. Die Beiträge befassen sich unter anderem mit den Baum- und Straucharten Kaukasiens - Teil IV Laubgehölze der Familien Globulariaceae bis Punicaceae (P. A. SchMIDT), der Struktur der Feinwurzeln von Metasequoia glyptostroboides (U. NOLDT und J. BAUCH), morphometrischen Populationsstudien zur Abgrenzung natürlicher Vorkommen der Wildbirne Pyrus pyraster von verwilderten Kulturbirnen $P$. communis (N. GLÄSSER und V. WiSSEMANN) und der Verwendungseignung von Rhododendron-Hybriden unter konti- nentalen Klimabedingungen (H.-H. JESCH et al.). Unter den Arbeiten finden sich auch zwei äußerst interessante Biographien über den bedeutenden Dendrologen C. A. SchencK (1868-1955) und den Botaniker F. T. PuRsCH (später PURSH, 1774-1820). Weiterhin enthält der Band Beiträge über Erfahrungen mit Abies-Arten in Südwestdeutschland, Birken des Himalaya, die Gattung Larix und ihre Zapfen, seltene Cultivare der Gattung Catalpa, Pyrus-Arten und Birnengitterrost, Schwarzkiefern auf Korsika sowie historische Gutsparks am Rande der Holsteinischen Schweiz. Im Reisebericht werden Eindrücke der 6-tägigen Jahrestagung in Meran mit ihren Exkursionen zur Vielfalt Südtirols wiedergegeben. Der 90. Band schließt mit Rezensionen gehölzkundlich interessanter Bücher sowie einem Register der botanischen Pflanzennamen.

Der vorliegende Band wird dem traditionellen Anspruch der Gesellschaft nach hoher Sachkunde zum Thema „Gehölze“ wieder voll gerecht. Die wissenschaftlich orientierten Beiträge bestätigen, dass die Mitteilungen auch außerhalb der DDG als Forum geschätzt werden. Die seit dem Jahr 2000 ansprechend eingebundenen Mitteilungen dürfen im Bücherschrank eines an wissenschaftlicher und praktischer Gehölzkunde Interessierten nicht fehlen.

Title: „Yearbook of the German Dendrologic Society No. 90 “.

M. LIESEBACH (Waldsieversdorf)

\footnotetext{
Herausgeberin: Bundesforschungsanstalt für Forst- und Holzwirtschaft: Schriftleitung: Institut für Forstgenetik und Forstpflanzenzüchtung, Siekerlandstrasse 2, D-22927 Grosshansdorf - Verlag: J. D. Sauerländer's Verlag, Finkenhofstrasse 21, D-60322 Frankfurt a. M. Anzeigenverwaltung: J. D. Sauerländer's Verlag, Frankfurt am Main. Satz: Satz- und Grafikstudio König, Marburg — Druck: ADN Offsetdruck, Battenberg — Printed in Germany.
} 